J. Braz. Chem. Soc., Vol. 16, No. 3B, 626-633, 2005.

Printed in Brazil - (O2005 Sociedade Brasileira de Química

$0103-5053 \$ 6.00+0.00$

\title{
Racemic Synthesis of 1,2-Secomicrominutinin
}

\section{Rosangela da Silva*,a, Paulo Marcos Donate ${ }^{a}$, Gil Valdo José da Silva ${ }^{a}$, Susimaire Pedersoli ${ }^{a}$ and Carlos Alemán ${ }^{b}$}

a Departamento de Química, Faculdade de Filosofia, Ciências e Letras de Ribeirão Preto, Universidade de São Paulo, Av. Bandeirantes, 3900, 14040-901 Ribeirão Preto - SP, Brazil

${ }^{b}$ Departament d'Enginyería Química, E.T.S. d'Enginyers Industrials de Barcelona, Universitat Politécnica de Catalunya, Diagonal 647, Barcelona E-08028, Spain

A 1,2-secomicrominutinina (25) racêmica foi sintetizada empregando-se a reação de cicloadição intramolecular de um alceniloxiceteno, preparado a partir do correspondente tosilato. $\mathrm{O}$ alceniloxiceteno sofre reação de cicloadição [2+2] intramolecular originando uma benzociclobutafuranona tricíclica (16) que, por oxidação de Bayer-Villiger, fornece uma benzofurofuranona (17). Reação desta última com propiolato de metila, catalisada por trifenilfosfina, produziu o derivado de éster cinâmico (25).

The racemic 1,2-secomicrominutinin (25) was synthesized employing the intramolecular cycloaddition reaction of an (alkenyloxy)ketene, prepared from the corresponding tosylate. The (alkenyloxy)ketene undergoes intramolecular [2+2] cycloaddition to give tricyclic benzocyclobutafuranone (16), which by Baeyer-Villiger oxidation gives a benzofuranofuranone (17). Reaction of the latter compound with methyl propiolate, catalyzed by triphenylphosphine, produced the cinnamic ester derivative (25).

Keywords: 1,2-secomicrominutinin, benzofuranofuran, intramolecular cycloaddition, synthesis

\section{Introduction}

The skeleton of the tricyclic compound 3a,8a-dihydro$2 \mathrm{H}, 3 \mathrm{H}, 3 \mathrm{aH}, 8 \mathrm{aH}-$ benzo[ $b]$ oxolano[3,2- $d]$ furan (1) appears as a moiety in a large number of natural products ${ }^{1-4}$ (Figure 1).

These compounds are of special interest since they show very interesting properties depending on their chemical constitution. Many of them are highly toxic, mutagenic or carcinogenic, like aflatoxin B2 (2), a secondary fungal metabolite produced by certain strains of Aspergillus flavus. ${ }^{1}$ They can also have useful properties due to their biological and pharmaceutical activity, like the antimalarial activity ${ }^{2}$ presented by pseudosemiglabrin derivatives (3 and 4), two flavonoid metabolites isolated from a subtropical plant of the genus Tephrosia. And there still is the anticoagulant activity ${ }^{3}$ of coumarins 5 and $\mathbf{6}$.

Several biologically active compounds, some of which with the basic structure 1, were isolated from Micromelum species, of the family Rutaceae, which are plants encountered in Asia, where they are traditionally used in folk medicine in the treatment of rheumatism, muscular

* e-mail: rosilva@usp.br<smiles>c1ccc2c(c1)O[C@H]1CCO[C@H]21</smiles><smiles>[R]O[C@H]1[C@H]2c3c(ccc4c(=O)cc(-c5ccccc5)oc34)O[C@H]2OC1(C)C</smiles>

$3, R=A c$
$4, R=H$<smiles>COc1cc2c(c3oc(=O)c4c(c13)CCC4)[C@H]1CCO[C@@H]1O2</smiles>

2

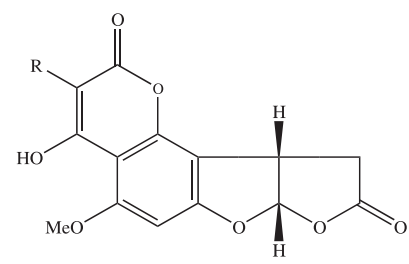

5, $\mathrm{R}=\mathrm{H}$

6, $\mathrm{R}=\mathrm{Me}$
Figure 1. Benzo[b]furano[3,2-d]furan compounds.

atrophy and fever of different origins. ${ }^{4}$ The coumarin microminutinin (7), and the dihydrocinnamic acid derivatives 3,4-dihydro-1,2-secomicrominutinin (8a) and 3,4-dihydro-1,2-secomicrominutinin methyl ester (8b) are three natural products that contain the same 3-methylene- 
2,3a,8a-trihydrobenzo[ $b]$ furano[3,2- $d]$ furan moiety in their structures (Figure 2), which have been recently isolated ${ }^{4}$ from the leaves of the shrub Micromelum falcatum.

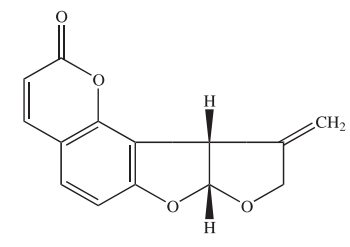

7

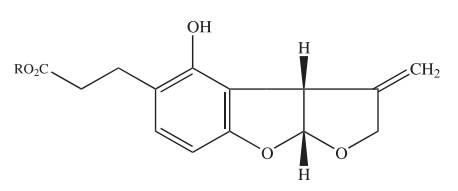

8a, $\mathrm{R}=\mathrm{H}$ $\mathbf{8 b}, \mathrm{R}=\mathrm{Me}$
Figure 2. 3-Methylene-2,3a,8a-trihydrobenzo[b]furano[3,2- $d]$ furan compounds.

Although the relevant biological and chemical properties of these natural products have translated into considerable synthetic interest; the syntheses of the natural products $\mathbf{7}$ and $\mathbf{8}$ have not been reported yet. Recently, we described the syntheses and the conformational studies ${ }^{5}$ of several model compounds of natural products containing the basic benzofuranofuran skeleton. The intramolecular $[2+2]$ cycloaddition of alkoxyketenes with alkenes, developed by Snider et al. ${ }^{6}$ and by Brady et al., ${ }^{7}$ was used as a useful synthetic method in the preparation of these polycyclic compounds. As part of our interest in the synthesis of a family of compounds bearing the benzofuranofuran moiety, this methodology was also used to synthesize, for the first time, the racemic cinnamic ester derivative 1,2-secomicrominutinin (25).

\section{Results and Discussion}

The synthesis started with the treatment of commercial methyl 2,6-dihydroxybenzoate with benzyl bromide and tetrabutylammonium fluoride (TBAF), to selectively protect only one of the hydroxyl groups, ${ }^{8}$ producing compound 9 in $85 \%$ yield (Scheme 1). Attempts to use other bases $(\mathrm{NaH}$, $\mathrm{KOH}, t$-BuOK) instead of TBAF favors the protection of both hydroxyl groups. The protection of the second hydroxyl group ${ }^{9}$ by reaction of $\mathbf{9}$ with methoxymethyl chloride and $N, N$-diisopropylethylamine (DIPEA) ${ }^{10}$ furnished compound $\mathbf{1 0}$ in $95 \%$ yield. The reduction of the carboxyl group ${ }^{11}$ of compound $\mathbf{1 0}$ with $\mathrm{LiAlH}_{4}$ furnished the corresponding alcohol $\mathbf{1 1}$ in $96 \%$ yield. The aldehyde $\mathbf{1 2}$ was obtained in $90 \%$ yield after the oxidation of $\mathbf{1 1}$ with pyridinium dichromate (PDC). ${ }^{12}$ Wittig reaction ${ }^{13}$ of $\mathbf{1 2}$ with ethylidenetriphenylphosphorane furnished compound $\mathbf{1 3}$ in $79 \%$ yield. Compound $\mathbf{1 4}$, with only one of the hydroxyl group deprotected, was obtained in $90 \%$ yield after selective cleavage of the methoxymethyl group of $\mathbf{1 3}$ with $\mathrm{HCl}$ in methanol. ${ }^{14}$ Reaction of $\mathbf{1 4}$ with bromoacetic acid produced compound $\mathbf{1 5}$ in $88 \%$ yield, which, after intramolecular $[2+2]$ cycloaddition reaction, ${ }^{6,7}$ furnished the tricyclic benzocyclobutafuranones $\mathbf{1 6}$ in $73 \%$ yield. The benzofuranofuranone $17(\mathrm{R}=\mathrm{Bn})$ was obtained in $81 \%$ yield through a Baeyer-Villiger oxidation of $\mathbf{1 6}$. Studies on the Baeyer-Villiger reaction indicate that the regioselectivity of asymmetric ketones is directed by the migratory aptitude of the groups adjacent to the carbonyl, reflecting the ability of the migrant group to accept a partial positive charge in the transition states. ${ }^{15}$ In the case of compound $\mathbf{1 6}$, the cationstabilizing effect of the unshared oxygen electron pairs increases the relative migratory aptitude of the attached carbon. Hydrogenolysis of the benzyl group of $\mathbf{1 7}$ produced the corresponding hydroxybenzofuranofuranone 18 ( $\mathrm{R}=$ $\mathrm{H}$ ), in $\mathbf{9 7 \%}$ yield, and $\mathbf{1 8}$ is an analogue of the biologically active compounds 5 and $\mathbf{6}$. Attempts to remove the protective benzyl group resulted in hydrogenation of the exocyclic double bond. Because of that, the hydroxyfuranone $\mathbf{1 8}$ was reacted with methoxymethyl chloride and $\mathrm{N}, \mathrm{N}$ diisopropylethylamine (DIPEA) ${ }^{10}$ to furnish the protected compound $19(\mathrm{R}=\mathrm{MOM})$ in $95 \%$ yield. Reaction of $\mathbf{1 9}$ with phenylselenenyl chloride, using LDA as a base, ${ }^{16}$ produced the selenophenyl derivative $\mathbf{2 0}$ in $\mathbf{7 0 \%}$ yield. Reaction of compound $\mathbf{2 0}$ with $\mathrm{H}_{2} \mathrm{O}_{2}$ at $0{ }^{\circ} \mathrm{C}$ furnished $98 \%$ of a mixture of the unsaturated furanone 21a with an exocyclic methylene group, and its isomer $\mathbf{2 1 b}$ with an endocyclic double bond (ratio 2:1). After the separation of the two isomers, the treatment of lactone 21a with diisobutylaluminium hydride (DIBAL-H) yielded lactol 22 (not isolated), which, by reaction with triethylsilane and trifluoroacetic acid, furnished ether $\mathbf{2 3}$ in $\mathbf{7 2} \%$ yield in two steps. ${ }^{17}$ The use of this two-step procedure, which joins a low-temperature reduction followed by a highly chemoselective deoxygenation, was more favorable in terms of operational simplicity and overall yield when compared with other methods. ${ }^{17}$ The methoxymethyl protective group in compound $\mathbf{2 3}$ was cleaved in $80 \%$ yield by treatment with $\mathrm{HCl}$ in methanol ${ }^{14}$ to produce 3 -methylene2,3a,8a,trihydro-benzo[b]furano[3,2- $d]$ furan-4-ol (24), which is a precursor of the natural products $\mathbf{7}$ and $\mathbf{8}$.

The traditional Pechmann reaction ${ }^{18}$ cannot be used to prepare the coumarinic ring of microminutinin (7) and its derivatives directly from compound $\mathbf{2 4}$ because this compound is very sensitive to the acidic conditions generally used in that reaction. Hoefnagel et al. ${ }^{19}$ synthesized several coumarins in moderate yields through the reaction of resorcinol and propynoic acid catalyzed by Amberlyst- 15 or zeolite H-beta, at $150{ }^{\circ} \mathrm{C}$. However, the ketal function of compound $\mathbf{2 4}$ was cleaved under these conditions. Yavari et al. ${ }^{20}$ obtained coumarins in good yields by the reaction between phenols and dimethyl 
<smiles>O=C(O)c1c(O)cccc1O</smiles><smiles>CC(C)C(C)Br</smiles><smiles>C/C=C/c1c(OC)cccc1OC</smiles>

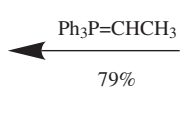
$\mathrm{MeOH}$ $\mathrm{HCl}$ cat.

$\sqrt{90 \%}$<smiles>C/C=C/c1c(O)cccc1OCc1ccccc1</smiles>

14

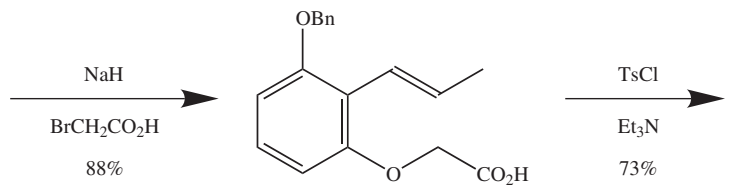

15<smiles></smiles>

20<smiles>CC(=O)c1c(O)cccc1O</smiles>

9

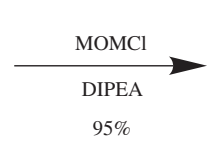<smiles>COc1cccc(OCc2ccccc2)c1C(C)=O</smiles>

10

\rfloor$^{\mathrm{LiAlH}_{4}}$<smiles>Cc1cccc(OCc2ccccc2)c1C=O</smiles><smiles>COc1cccc(OCc2ccccc2)c1CO</smiles>

11<smiles>C=C1C(=O)OC2Oc3cccc(OC)c3C12</smiles>
$21 \mathrm{a}$ DIBAL-H $\checkmark$<smiles>C=C1C2CCCC2C1Oc1cccc(OC)c1O</smiles>

22<smiles>C=C1COC2Oc3ccc(C=CC(=O)O)c(OC)c3C12</smiles>

23<smiles>C=C1COC2Oc3cccc(O)c3C12</smiles>

24

Scheme 1. Synthesis of 3-methylene-2,3a,8a,trihydro-benzo[b]furano[3,2- $d]$ furan-4-ol (24) from methyl 2,6-dihydroxybenzoate.

acetylenedicarboxylate in the presence of triphenylphosphine under reflux in dichloromethane. Nevertheless, decomposition of the starting material was also observed when this reaction was carried out with compound 24. Therefore, this latter methodology was adapted to be employed in very mild conditions. Under these milder conditions, the coumarinic ring is not produced, but instead, very interesting 1,2secomicrominutinin derivatives are obtained. These cinnamic ester derivatives are the unsaturated analogues of the natural product $\mathbf{8}$, and may be used as very valuable intermediates for the synthesis of natural products with the benzofuranofuran skeleton.

Thus, compound $\mathbf{2 4}$ and triphenylphosphine were dissolved in dichloromethane and a solution of methyl propiolate in dichloromethane was slowly added, maintaining the reaction mixture under stirring for 24 hours at room temperature. Analysis by ${ }^{1} \mathrm{H}$ NMR, ${ }^{13} \mathrm{C}$ NMR, MS, 
and IR revealed that the product obtained in $81 \%$ yield was a mixture of the unsaturated isomers $\mathbf{2 5}$ and $\mathbf{2 6}$ in the proportion of 2:1, respectively (Scheme 2). Presumably, these two isomers are formed because the electrophilic attack of the vinyltriphenylphosphonium cation (resulting from the initial addition of triphenylphosphine to the acetylenic ester followed by concomitant protonation $)^{20}$ on the aromatic ring of $\mathbf{2 4}$ is influenced by the strong ortho/para activating groups on the aromatic ring.

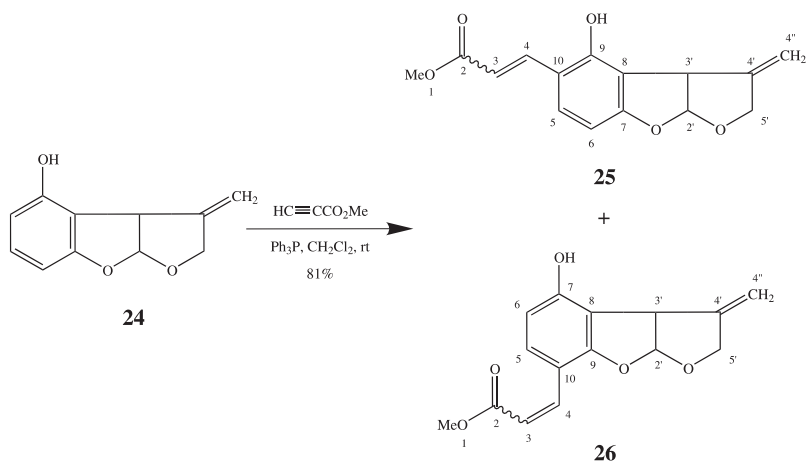

Scheme 2. Reaction of compound $\mathbf{2 4}$ with methyl propiolate in the presence of triphenylphosphine.

Stereochemical assignment of the acrylate double bond is usually based on the magnitude of the vicinal coupling constant of the corresponding hydrogens in the ${ }^{1} \mathrm{H}$ NMR spectra. The range for $E$ isomers is 12 to $18 \mathrm{~Hz}$, and 6 to 12 $\mathrm{Hz}$ for $\mathrm{Z}$ isomers. In this work, the measured values for compounds $\mathbf{2 5}$ and $\mathbf{2 6}$ were 12.1 and $12.4 \mathrm{~Hz}$, respectively, making an unequivocal attribution difficult. On the other hand, the chemical shifts of the hydrogens on the acrylic $\beta$-carbons of these compounds were 7.80 and 7.66, respectively. Based on numerous examples from the literature, ${ }^{21}$ we can suggest that the prepared compounds are $E$ isomers.

All attempts to obtain microminutinin (7) either straightforward from compound $\mathbf{2 4}$ by reaction with several kinds of reagents, ${ }^{18-20}$ or by the ring closure of the 1,2 secomicrominutinin (25) were unproductive. This failure can be another evidence for the fact that the double bond of compound $\mathbf{2 5}$ has an $E$ configuration, since it is wellknown that $E$ isomers of 3-(2-hydroxyaryl)propenoic esters are difficult to cyclize to the corresponding coumarins by traditional methods. ${ }^{21}$ The lability of the ketal function present in the compounds under investigation prevents the use of more drastic methods such as heating or pyrolisis.

\section{Conclusions}

We have reported the first successful racemic synthesis of the cinnamic ester derivative 1,2-secomicrominutinin
(25) by the intramolecular cycloaddition of an (alkenyloxy)ketene followed by the reaction, under mild conditions, of a benzofuranofuran moiety with methyl propiolate.

\section{Experimental}

All ${ }^{1} \mathrm{H}$ and ${ }^{13} \mathrm{C}$ NMR spectra were recorded at 300 and $75 \mathrm{MHz}$, respectively, using a Bruker DPX-300 instrument and chloroform- $d\left(\mathrm{CDCl}_{3}\right)$ as solvent; chemical shifts are in ppm downfield from tetramethylsilane internal standard. IR spectra were measured $\mathrm{KBr}$ ) with a Perkin Elmer Spectrum RX IFTIR System, and the most intense or representative bands are reported (in $\mathrm{cm}^{-1}$ ). Mass spectra were determined at an ionizing voltage of $70 \mathrm{eV}$, using a HP 5988-A spectrometer. The mass spectra of compounds 25 and 26 were performed by electronspray ionization (ESI), using a Micromass Quattro LC spectrometer. Solutions were infused into the Z-spray source at $10 \mu \mathrm{L} \mathrm{min}^{-1}$ $\left(0.5 \mathrm{mg} \mathrm{mL}^{-1}\right)$, and the protonated parent ions were observed at $\mathrm{m} / \mathrm{z}$ 275. TLC was performed on plates precoated with silica gel $60 \mathrm{~F}_{254}(0.25 \mathrm{~mm}$ thick, Merck) and column chromatography separations were performed with silica gel 60 (70-230 mesh, Merck). Melting points were determined on a Reichert Kofler block apparatus and are uncorrected.

Methyl 2-(benzyloxy)-6-hydroxybenzoate (9). A solution of methyl 2,6-dihydroxybenzoate (0.1002 g, $0.596 \mathrm{mmol}$ ) and tetrabutylammonium fluoride (TBAF) $(0.3751 \mathrm{~g}, 1.190 \mathrm{mmol})$ in DMF $(5 \mathrm{~mL})$ was stirred under nitrogen atmosphere for $15 \mathrm{~min}$. Benzyl bromide (0.1119 $\mathrm{g}, 0.650 \mathrm{mmol}$ ) was then added and the reaction mixture was stirred at room temperature for $3 \mathrm{~h}$, and it was subsequently diluted with water $(5 \mathrm{~mL})$ and ethyl ether $(10 \mathrm{~mL})$. The organic phase was separated, washed with water and with saturated brine. The combined extracts were dried over $\mathrm{MgSO}_{4}$, filtered and evaporated to give the crude product, which was purified by column chromatography through silica gel, using $n$-hexane:ethyl acetate $(8: 2)$ as eluent, to afford $9(1.3075 \mathrm{~g}, 85 \%)$ as a colorless oil; ${ }^{1} \mathrm{H}$ NMR $\left(300 \mathrm{MHz} \mathrm{CDCl}_{3}\right) \delta 11.5(\mathrm{~s}, 1 \mathrm{H}), 7.5(\mathrm{~s}, 5 \mathrm{H}), 7.3-6.5$ $(\mathrm{m}, 3 \mathrm{H}), 5.2(\mathrm{~s}, 2 \mathrm{H}), 4.0(\mathrm{~s}, 3 \mathrm{H})$; IR $v_{\max } / \mathrm{cm}^{-1}: 3337,3008$, 1732, 1200, 1030, 841; MS m/z (relative intensity) 210 $\left[\mathrm{M}^{+}-(\mathrm{OMe}+\mathrm{OH}), 10\right], 180$ (2), 91 (100), 65 (12), 45 (50), 28 (31).

Methyl 2-(benzyloxy)-6-(methoxymethoxy)benzoate (10). $N, N$-Diisopropylethylamine (DIPEA) (0.0319 g, $0.247 \mathrm{mmol}$ ) was added slowly to a stirred solution of compound 9 (0.0525 g, $0.204 \mathrm{mmol})$ and chloromethyl methyl ether (MOMCl) $(0.0181 \mathrm{~g}, 0.225 \mathrm{mmol})$ in $\mathrm{CH}_{2} \mathrm{Cl}_{2}$ $(5 \mathrm{~mL})$, cooled to $0{ }^{\circ} \mathrm{C}$ under anhydrous conditions. The 
mixture was stirred at room temperature for $24 \mathrm{~h}$, and it was diluted with water $(3 \times 10 \mathrm{~mL})$ and $\mathrm{CH}_{2} \mathrm{Cl}_{2}(10 \mathrm{~mL})$. The phases were separated, and the organic phase was dried over $\mathrm{MgSO}_{4}$, filtered and evaporated to give the crude product, which was purified by column chromatography through silica gel, using $n$-hexane:ethyl acetate (1:1) as eluent, to afford $\mathbf{1 0}(0.0585 \mathrm{~g}, 95 \%)$ as a colorless oil; ${ }^{1} \mathrm{H}$ NMR (300 MHz, $\left.\mathrm{CDCl}_{3}\right) \delta 7.5(\mathrm{~s}, 5 \mathrm{H}), 7.4-6.7$ (m, 3H), 5.2 (s, 2H), 5.1 (s, 2H), 3.8 (s, 3H), $3.5(\mathrm{~s}, 3 \mathrm{H}) ;{ }^{13} \mathrm{C} \mathrm{NMR}(75$ $\left.\mathrm{MHz}, \mathrm{CDCl}_{3}\right) \delta 167.0,164.2$ (2 C-O arom), 140.8, 134.8, 128.4 (2 CH arom), 127.3 (2 CH arom), 127.2, 106.1 (2 CH arom), 101.7, 100.7, 77.8, 50.2, 50.1; IR $v_{\max } / \mathrm{cm}^{-1}: 3005$, $1603,1730,1200,1151,1033,841$; MS $\mathrm{m} / \mathrm{z}$ (relative intensity) $257\left[\left(\mathrm{M}^{+}-\mathrm{CH}_{2} \mathrm{OCH}_{3}\right), 7\right], 121$ (5), 91 (100), 65 (12), 45 (55) 28 (50).

[2-(Benzyloxy)-6-(methoxymethoxy)phenyl]methanol (11). A solution of compound $\mathbf{1 0}(2.5402 \mathrm{~g}, 8.41 \mathrm{mmol})$ in THF (2 mL) was added to a stirred suspension of $\mathrm{LiAlH}_{4}$ $(0.5370 \mathrm{~g}, 14.0 \mathrm{mmol})$ in THF (30 mL), under anhydrous conditions. The mixture was refluxed for $3 \mathrm{~h}$, cooled to $0{ }^{\circ} \mathrm{C}$, and then water $(2.5 \mathrm{~mL})$ and a solution of $\mathrm{NaOH} 3 \mathrm{~mol}$ $\mathrm{L}^{-1}(0.640 \mathrm{~mL})$ were added. The precipitate was separated by filtration and the resulting solution was extracted with ethyl ether. The organic phase was dried over $\mathrm{MgSO}_{4}$, filtered and evaporated to give the crude product, which was purified by column chromatography through silica gel, using with $n$-hexane:ethyl acetate (1:1) as eluent, to afford 11 (2.2126 $\mathrm{g}, 96 \%)$ as a colorless oil; ${ }^{1} \mathrm{H} \mathrm{NMR}\left(300 \mathrm{MHz}, \mathrm{CDCl}_{3}\right) \delta 7.5$ (m, 5H), 7.4-6.7 (m, 3H), $5.2(\mathrm{~s}, 2 \mathrm{H}), 5.1(\mathrm{~s}, 2 \mathrm{H}), 4.8(\mathrm{~s}, 2 \mathrm{H})$, $3.5(\mathrm{~s}, 3 \mathrm{H}), 2.5(\mathrm{~s}, 1 \mathrm{H}) ;{ }^{13} \mathrm{C} \mathrm{NMR}\left(75 \mathrm{MHz}, \mathrm{CDCl}_{3}\right) \delta 161.8$ (2 C-O arom), 140.9, 129.4, 128.7 (2 CH arom), $127.4(2 \mathrm{CH}$ arom), 127.3, 112.1, 106.6 (2 CH arom), 101.0, 78.1, 50.2, 48.7; IR $v_{\max } / \mathrm{cm}^{-1}: 3300,3005,1600,1475,1200,1151$, $1033,841,735 ; \mathrm{MS} \mathrm{m} / \mathrm{z}$ (relative intensity) $213\left[\left(\mathrm{M}^{+}\right.\right.$$\left.\left.\mathrm{OCH}_{2} \mathrm{OCH}_{3}\right), 5\right], 91$ (100), 45 (53), 28 (19).

2-(Benzyloxy)-6-(methoxymethoxy)benzaldehyde (12). A solution of compound 11 (1.8303 g, $6.68 \mathrm{mmol})$ in anhydrous $\mathrm{CH}_{2} \mathrm{Cl}_{2}(10 \mathrm{~mL})$ was added to a stirred solution of pyridinium dichromate (PDC) $(5.0021 \mathrm{~g}, 13.3 \mathrm{mmol})$ in anhydrous $\mathrm{CH}_{2} \mathrm{Cl}_{2}(50 \mathrm{~mL})$. The reaction mixture was stirred at room temperature for $48 \mathrm{~h}$, then the suspension was filtered through Celite ${ }^{\circledR}$, and the solvent was evaporated to give the crude product, which was purified by column chromatography through silica gel, using dichloromethane:ethyl acetate $(8: 2)$ as eluent, to afford $12(1.6358 \mathrm{~g}, 90 \%)$ as a white solid; mp $38-40{ }^{\circ} \mathrm{C} .{ }^{1} \mathrm{H}$ NMR $\left(300 \mathrm{MHz} \mathrm{CDCl}_{3}\right) \delta 10.5(\mathrm{~s}, 1 \mathrm{H}), 7.5(\mathrm{~m}, 5 \mathrm{H}), 7.4-6.7$ (m, $3 \mathrm{H}), 5.2(\mathrm{~s}, 2 \mathrm{H}), 5.1(\mathrm{~s}, 2 \mathrm{H}), 3.5(\mathrm{~s}, 3 \mathrm{H}),{ }^{13} \mathrm{C} \mathrm{NMR}(75 \mathrm{MHz}$, $\left.\mathrm{CDCl}_{3}\right) \delta$ 190.0, 164.2 (2 C-O arom), 140.7, 136.3, 128.7 (2 CH arom), 127.4, 127.3 (2 CH arom), 107.9, 106.9 (2 $\mathrm{CH}$ arom), 100.7, 77.8, 50.1; IR $v_{\max } / \mathrm{cm}^{-1}: 3010,2825$,
$1705,1603,1475,1200,1157,841,730 ;$ MS $m / z$ (relative intensity) $211\left[\left(\mathrm{M}^{+}-\mathrm{OCH}_{2} \mathrm{OCH}_{3}\right), 2\right], 180$ (2), 91 (100), 56 (12), 45 (50).

1-(Benzyloxy)-3-(methoxymethoxy)-2-[(1E)-prop-1-en1-yl]benzene (13). $n$-Butyllithium $(8.720 \mathrm{~mL}, 8.46 \mathrm{mmol}$, $0.97 \mathrm{~mol} \mathrm{~L}^{-1}$ in $n$-hexane) was added to a stirred solution of (ethyl)triphenylphosphonium bromide (3.1398 g, 8.46 mmol) in THF ( $5 \mathrm{~mL})$ at $-78{ }^{\circ} \mathrm{C}$, under anhydrous conditions. The cooling bath was removed, and the reaction mixture was stirred at room temperature for 20 $\min$. The reaction mixture was cooled again at $-78^{\circ} \mathrm{C}$, and a solution of compound $12(1.1552 \mathrm{~g}, 4.25 \mathrm{mmol})$ in THF ( $4 \mathrm{~mL}$ ) was added. The reaction mixture was then stirred at room temperature for $1 \mathrm{~h}$, diluted with water $(5 \mathrm{~mL})$ and extracted with ethyl ether $(15 \mathrm{~mL})$. The organic phase was washed with water and with saturated brine, dried over $\mathrm{MgSO}_{4}$, filtered, and the solvent was evaporated to give the crude product, which was purified by column chromatography through silica gel, using $n$-hexane:ethyl acetate (9:1) as eluent, to afford $\mathbf{1 3}(0.9540 \mathrm{~g}, 79 \%$ yield $)$ as a colorless oil; ${ }^{1} \mathrm{H} \mathrm{NMR}\left(300 \mathrm{MHz}, \mathrm{CDCl}_{3}\right) \delta 7.45(\mathrm{~m}$, $5 \mathrm{H}), 7.40-6.71(\mathrm{~m}, 3 \mathrm{H}), 6.30-5.90(\mathrm{~m}, 2 \mathrm{H}), 5.21(\mathrm{~s}, 2 \mathrm{H})$, $5.10(\mathrm{~s}, 2 \mathrm{H}), 3.50(\mathrm{~s}, 3 \mathrm{H}), 1.90(\mathrm{~d}, J 9.0 \mathrm{~Hz}, 3 \mathrm{H}) ;{ }^{13} \mathrm{C} \mathrm{NMR}$ (75 MHz, $\mathrm{CDCl}_{3}$ ) $\delta 160.8$ (2 C-O arom), 140.7, 129.7, 128.7 (2 CH arom), 128.4, 127.4, 127.3 (2 CH arom), 121.7, 106.3 (2 CH arom), 106.0, 101.1, 78.2, 50.2, 16.6; IR $v_{\max } / \mathrm{cm}^{-1}$ : $3005,1607,1478,1200,1151,837,729 ;$ MS $m / z$ (relative intensity) $239\left[\left(\mathrm{M}^{+}-\mathrm{CH}_{2} \mathrm{OCH}_{3}\right), 4\right], 193$ (4), 161 (15), 91 (100), 65 (15), 45 (62), 28 (38).

3-(Benzyloxy)-2-[(1E)-prop-1-en-1-yl]phenol(14). One drop of concentrated $\mathrm{HCl}$ was added to a stirred solution of compound 13 (0.1002 g, $0.353 \mathrm{mmol})$ in methanol (20 $\mathrm{mL}$ ). The reaction mixture was stirred at room temperature for $24 \mathrm{~h}$, the solvent was evaporated, and the residue was purified by column chromatography through silica gel, using $n$-hexane:ethyl acetate (8:2) as eluent, to afford $\mathbf{1 4}$ $(0.0763 \mathrm{~g}, 90 \%)$ as a colorless oil. ${ }^{1} \mathrm{H}$ NMR (300 MHz, $\left.\mathrm{CDCl}_{3}\right) \delta 7.5(\mathrm{~m}, 5 \mathrm{H}), 7.4-6.7(\mathrm{~m}, 3 \mathrm{H}), 6.3-5.9(\mathrm{~m}, 2 \mathrm{H}), 5.2$ (s, 2H), 4.5 (s, 1H), $1.9(\mathrm{~d}, J 9.1 \mathrm{~Hz}, 3 \mathrm{H}) ;{ }^{13} \mathrm{C} \mathrm{NMR}(75 \mathrm{MHz}$, $\left.\mathrm{CDCl}_{3}\right) \delta 161.1,156.0,140.9,130.1,128.7$ (2 CH arom), 128.4, 127.4, 127.3 (2 CH arom), 121.7, 107.9, 107.7, 106.6, 78.2, 16.4; IR $v_{\max } / \mathrm{cm}^{-1}: 3370,3005,1603,1475$, 1200, 1151, 841, 735; MS $m / z$ (relative intensity) $240\left(\mathrm{M}^{+}\right.$, 100), 199 (7), 161 (15), 149 (50), 91 (98), 66 (15).

\{3-(Benzyloxy)-2-[(1E)-prop-1-en-1-yl]phenoxy\}acetic acid (15). A solution of compound 14 (0.4002 g, 1.67 $\mathrm{mmol})$ in THF ( $2 \mathrm{~mL}$ ) was added to a stirred suspension of $\mathrm{NaH}$ (0.1659 g, $4.15 \mathrm{mmol})$ in THF (15 mL), under anhydrous conditions. The reaction mixture was stirred at room temperature for $20 \mathrm{~min}$, and then a solution of bromoacetic acid $(0.2540 \mathrm{~g}, 1.66 \mathrm{mmol})$ in THF $(1 \mathrm{~mL})$ 
was added. The reaction mixture was refluxed for $6 \mathrm{~h}$, and it was then, stirred overnight at room temperature, diluted with ethyl ether and quenched with saturated brine $(8 \mathrm{~mL})$. The aqueous phase was separated, washed with ethyl ether, acidified with $\mathrm{HCl} 6 \mathrm{~mol} \mathrm{~L}^{-1}$ until $\mathrm{pH} 1$ and extracted with ethyl ether $(3 \times 15 \mathrm{~mL})$. The organic phase was washed with water and with saturated brine, dried over $\mathrm{MgSO}_{4}$, filtered, and the solvent was evaporated to furnish compound $15(0.4381 \mathrm{~g}, 88 \%$ yield $)$ as a viscous oil. ${ }^{1} \mathrm{H}$ NMR (300 MHz, $\left.\mathrm{CDCl}_{3}\right) \delta 11.0(\mathrm{~s}, 1 \mathrm{H}), 7.5(\mathrm{~m}, 5 \mathrm{H}), 7.4-$ $6.7(\mathrm{~m}, 3 \mathrm{H}), 6.3-5.9(\mathrm{~m}, 2 \mathrm{H}), 5.2(\mathrm{~s}, 2 \mathrm{H}), 4.7(\mathrm{~s}, 2 \mathrm{H}), 1.7(\mathrm{~d}$, $J 9.1 \mathrm{~Hz}, 3 \mathrm{H}) ;{ }^{13} \mathrm{C} \mathrm{NMR}\left(75 \mathrm{MHz}, \mathrm{CDCl}_{3}\right) \delta 176.0,160.7$ (2 C-O-arom), 140.7, 129.5, 128.6 (2 CH arom), 128.4, 127.4, 127.3 (2 CH arom), 121.7, 106.2 (2 CH arom), 106.0, 78.2, 78.0, 15.3; IR $v_{\max } / \mathrm{cm}^{-1}: 3294,3005,1717,1408,1200$, $1151,932,841,735 ; \mathrm{MS} \mathrm{m} / \mathrm{z}$ (relative intensity) $298\left(\mathrm{M}^{+}\right.$, 2), 207 (20), 161 (30), 147 (6), 91 (100), 65 (16), 28 (40).

7 - (Be nzyloxy) - 1-methyl-2a, $7 b$ dihydrobenzo[b]cyclobuta[d]furan-2(1H)-one (16). A solution of acid $15(0.4502 \mathrm{~g}, 1.51 \mathrm{mmol})$ in benzene (50 $\mathrm{mL}$ ) was added slowly $(5 \mathrm{~h})$ to a stirred solution of triethylamine $(2.110 \mathrm{~mL}, 15.1 \mathrm{mmol})$, tosyl chloride $(0.5741 \mathrm{~g}, 3.01 \mathrm{mmol})$ in benzene $(50 \mathrm{~mL})$, under reflux. After $6 \mathrm{~h}$ under reflux, the reaction mixture was washed with water $(3 \times 10 \mathrm{~mL})$ and concentrated to $10 \mathrm{~mL}$, under reduced pressure. This concentrated solution was stirred for $10 \mathrm{~h}$ at room temperature, with a solution of $3 \% \mathrm{NaOH}$ $(20 \mathrm{~mL})$, to remove excess tosyl chloride. The organic phase was separated, dried over $\mathrm{MgSO}_{4}$, filtered, the solvent was evaporated, and the residue was purified by column chromatography through silica gel, using $n$ hexane:ethyl acetate (8:2) as eluent, to afford $\mathbf{1 6}(0.3088$ $\mathrm{g}, 73 \%)$ as a colorless oil. ${ }^{1} \mathrm{H} \mathrm{NMR}\left(300 \mathrm{MHz}, \mathrm{CDCl}_{3}\right) \delta$ $7.5(\mathrm{~m}, 5 \mathrm{H}), 7.3-6.8(\mathrm{~m}, 3 \mathrm{H}), 5.6(\mathrm{dd}, J 8.4 \mathrm{and} 2.9 \mathrm{~Hz}, 1 \mathrm{H})$, $5.2(\mathrm{~s}, 2 \mathrm{H}), 4.3(\mathrm{dd}, J 8.4 \mathrm{~Hz}$ and $8.7 \mathrm{~Hz}, 1 \mathrm{H}), 3.8(\mathrm{~m}, 1 \mathrm{H})$, $1.1(\mathrm{~d}, J 7.3 \mathrm{~Hz}, 3 \mathrm{H}) ;{ }^{13} \mathrm{C} \mathrm{NMR}\left(75 \mathrm{MHz}, \mathrm{CDCl}_{3}\right) \delta 211.3$, 162.4, 159.6, 140.9, 128.7 (2 CH arom), 127.4 (2 $\mathrm{CH}$ arom), 127.3 (2 CH arom), 110.1, 106.3, 105.9, 85.2, 78.1, 43.0, 30.2, 13.3; IR $v_{\text {max }} / \mathrm{cm}^{-1}: 2995,1725,1475,1205,1033$, 841, 735; MS m/z (relative intensity) $280\left(\mathrm{M}^{+}, 3\right), 251$ (5), 160 (15), 91 (100), 66 (15), 45 (51).

4-(Benzyloxy)-3-methyl-3a,8a-dihydrofuro [2,3b][1]benzofuran-2(3H)-one (17). Solid $\mathrm{NaHCO}_{3}(0.0990 \mathrm{~g}$, $1.17 \mathrm{mmol})$ and solid $m$-chloroperoxybenzoic acid (MCPBA) 85\% (0.0831 g, $0.409 \mathrm{mmol}$ ) were quickly added to a stirred solution of compound $\mathbf{1 6}(0.1101 \mathrm{~g}, 0.393 \mathrm{mmol})$ in anhydrous $\mathrm{CH}_{2} \mathrm{Cl}_{2}(10 \mathrm{~mL})$. The reaction mixture was stirred at room temperature for $30 \mathrm{~min}$ and then it was diluted with $\mathrm{CH}_{2} \mathrm{Cl}_{2}(10 \mathrm{~mL})$ and with a solution of $10 \% \mathrm{NaHCO}_{3}$ $(5 \mathrm{~mL})$. The organic phase was washed with saturated brine, dried over $\mathrm{MgSO}_{4}$, filtered, the solvent was evaporated, and the residue was purified by column chromatography through silica gel, using $n$-hexane:ethyl acetate (8:2) as eluent, to afford $\mathbf{1 7}(0.0943 \mathrm{~g}, 81 \%)$ as a white solid: $\mathrm{mp} 82-85^{\circ} \mathrm{C} .{ }^{1} \mathrm{H}$ NMR (300 MHz, $\left.\mathrm{CDCl}_{3}\right) \delta 7.4(\mathrm{~m}, 5 \mathrm{H}), 7.3-6.5(\mathrm{~m}, 3 \mathrm{H}), 6.5$ $(\mathrm{d}, 1 \mathrm{H}, J 6.6 \mathrm{~Hz}, 1 \mathrm{H}), 5.1$ (s, 2H), $4.4(\mathrm{dd}, J 6.6$ and $10.3 \mathrm{~Hz}$, 1H), $3.1(\mathrm{~m}, 1 \mathrm{H}), 1.3(\mathrm{~d}, J 7.3 \mathrm{~Hz}, 3 \mathrm{H}) ;{ }^{13} \mathrm{C}$ NMR $(75 \mathrm{MHz}$, $\left.\mathrm{CDCl}_{3}\right) \delta 177.6,159.5,156.5,136.3,131.2,128.7(2 \mathrm{CH}$ arom), 127.4, 127.3 (2 CH arom), 111.0, 106.7, 105.5, 103.8, 77.2, 45.6, 37.7, 13.3; IR $v_{\max } / \mathrm{cm}^{-1}: 2998,1727,1475,1200$, 1023, 841, 735; MS $m / z$ (relative intensity) $296\left(\mathrm{M}^{+}, 3\right), 91$ (100), 65 (12), 28 (73).

4-Hydroxy-3-methyl-3a,8a-dihydrofuro [2,3b][1]benzofuran-2(3H)-one (18). A solution of compound $17(0.1502 \mathrm{~g}, 0.507 \mathrm{mmol})$ in methanol $(10 \mathrm{~mL})$ was hydrogenated under $1 \mathrm{~atm}$ at room temperature, with a catalyst containing $5 \%$ palladium on activated carbon powder (amount not determined). When one equivalent of hydrogen had been consumed (about 1h), the catalyst was removed by filtration through Celite ${ }^{\circledast}$, and the solvent was evaporated under reduced pressure. The residue was purified by column chromatography through silica gel, using $n$-hexane:ethyl acetate (1:1) as eluent, to afford $\mathbf{1 8}$ $(0.1014 \mathrm{~g}, 97 \%$ yield $)$ as a white solid: $\mathrm{mp} 166-168^{\circ} \mathrm{C}$. ${ }^{1} \mathrm{H}$ NMR $\left(300 \mathrm{MHz}, \mathrm{CDCl}_{3}\right) \delta 7.3-6.5$ (m, 3H), 6.5 (d, J 6.6 $\mathrm{Hz}, 1 \mathrm{H}), 6.0$ (br s, 1H), 4.4 (dd, $J 6.6$ and $10.3 \mathrm{~Hz}, 1 \mathrm{H}), 3.1$ $(\mathrm{m}, 1 \mathrm{H}), 1.3(\mathrm{~d}, J 7.3 \mathrm{~Hz}, 3 \mathrm{H}) ;{ }^{13} \mathrm{C} \mathrm{NMR}\left(75 \mathrm{MHz}, \mathrm{CDCl}_{3}\right) \delta$ 178.1, 160.3, 153.8, 131.4, 110.0, 109.8, 107.4, 103.8, 45.0, 38.4, 13.5; IR $v_{\max } / \mathrm{cm}^{-1}: 2995,1728,1475,1207$, $1023,845,735$; MS $\mathrm{m} / \mathrm{z}$ (relative intensity) $206\left(\mathrm{M}^{+}, 17\right)$, 177 (43), 147 (9), 121 (13), 105 (21), 45 (100).

4-(Methoxymethoxy)-3-methyl-3a,8a-dihydrofuro[2,3b][1]benzofuran-2(3H)-one (19). $N, N$-Diisopropylethylamine (DIPEA) $(0.020 \mathrm{~mL}, 0.12 \mathrm{mmol})$ was added to a stirred solution of compound $\mathbf{1 8}(0.0201 \mathrm{~g}, 0.098 \mathrm{mmol})$ in $\mathrm{CH}_{2} \mathrm{Cl}_{2}(2 \mathrm{~mL})$. After stirring for $10 \mathrm{~min}$ at room temperature, chloromethyl methyl ether (MOMCl) $(0.0101 \mathrm{~g}, 0.125$ mmol) was added. The reaction mixture was stirred for $24 \mathrm{~h}$ at room temperature, and then it was diluted with water $(5 \mathrm{~mL})$ and $\mathrm{CH}_{2} \mathrm{Cl}_{2}(5 \mathrm{~mL})$. The organic phase was separated, washed with saturated brine, dried over $\mathrm{MgSO}_{4}$, filtered, and the solvent was evaporated under reduced pressure. The residue was purified by column chromatography through silica gel, using $n$-hexane:ethyl acetate (7:3) as eluent, to afford 19 ( $0.0233 \mathrm{~g}, 95 \%$ yield) as a colorless oil. ${ }^{1} \mathrm{H}$ NMR (300 MHz, $\left.\mathrm{CDCl}_{3}\right) \delta 7.3-6.5(\mathrm{~m}, 3 \mathrm{H}), 6.5(\mathrm{~d}, J 6.6 \mathrm{~Hz}, 1 \mathrm{H})$, 5.2 (s, 2H), 4.4 (dd, $J 6.6$ and $10.3 \mathrm{~Hz}, 1 \mathrm{H}), 3.5$ (s, 3H), 3.1 $(\mathrm{m}, 1 \mathrm{H}), 1.3(\mathrm{~d}, J 7.3 \mathrm{~Hz}, 3 \mathrm{H}) ;{ }^{13} \mathrm{C} \mathrm{NMR}\left(75 \mathrm{MHz}, \mathrm{CDCl}_{3}\right)$ $\delta$ 177.9, 159.8, 155.4, 131.6, 111.9, 107.8, 107, 104.7, 94.9, 56.8, 45.9, 38.1, 13.6; IR $v_{\max } / \mathrm{cm}^{-1}: 2995,1728,1602,1470$, 1200, 1033, 845, 735; MS m/z (relative intensity) 205 [( $\left.\left.\mathrm{M}^{+}-\mathrm{CH}_{2} \mathrm{OCH}_{3}\right), 9\right], 176$ (43), 160 (100), 91 (55), 77 (30). 
4-(Methoxymethoxy)-3-methyl-3-(phenylsulfanyl)3a,8a-dihydrofuro[2,3-b][1]benzo-furan-2(3H)-one (20). $n$-Butyllithium $\left(0.050 \mathrm{~mL}, 0.10 \mathrm{mmol}, 2.2 \mathrm{~mol} \mathrm{~L}^{-1}\right.$ in $n$ hexane) was added to a stirred solution of diisopropylamine $(0.015 \mathrm{~mL}, 0.10 \mathrm{mmol})$ in anhydrous THF $(5 \mathrm{~mL})$, cooled to $0{ }^{\circ} \mathrm{C}$ under anhydrous conditions. After $20 \mathrm{~min}$, the mixture was cooled at $-78{ }^{\circ} \mathrm{C}$ and compound 19 (0.0211 $\mathrm{g}, 0.084 \mathrm{mmol}$ ) was added, and the resulting mixture was stirred for an additional $30 \mathrm{~min}$. Phenylselenenyl bromide $(0.0240 \mathrm{~g}, 0.10 \mathrm{mmol})$ was added, and the bath temperature was allowed to rise slowly until $-20{ }^{\circ} \mathrm{C}$. The reaction mixture was stirred for $2 \mathrm{~h}$, diluted with a saturated solution of $\mathrm{NH}_{4} \mathrm{Cl}(4 \mathrm{~mL})$ and extracted with ethyl ether. The organic phase was dried over $\mathrm{MgSO}_{4}$, filtered, and the solvent was evaporated under reduced pressure. The residue was purified by flash chromatography, using $n$-hexane:ethyl acetate (9:1) as eluent, to afford $20(0.0239 \mathrm{~g}, 70 \%$ yield $)$ as a yellow oil; ${ }^{1} \mathrm{H} \mathrm{NMR}\left(300 \mathrm{MHz}, \mathrm{CDCl}_{3}\right) \delta 7.4(\mathrm{~s}, 5 \mathrm{H})$, 7.3-6.5 (m, 3H), 6,5 (d, J 6.6 Hz, 1H), 5.2 (s, 2H), 4.4 (d, J $6.6 \mathrm{~Hz}, 1 \mathrm{H}), 3.5$ (s, 3H), 1,7 (s, 3H); ${ }^{13} \mathrm{C} \mathrm{NMR}(75 \mathrm{MHz}$, $\left.\mathrm{CDCl}_{3}\right) \delta 175.0,162.7,159.6,128.5,128.0$ (5 CH arom), 127.2, 110.1, 106.8, 105.8, 105.0, 101.1, 50.3, 50.1, 23.1, 9.2; IR $v_{\max } / \mathrm{cm}^{-1}: 2997,1725,1475,1207,1023,845,735$. 4-(Methoxymethoxy)-3-methylene-3a,8a-dihydrofuro[2,3b][1]benzofuran-2(3H)-one (21a). To a stirred solution of compound $20(0.0210 \mathrm{~g}, 0.050 \mathrm{mmol})$ in $\mathrm{CH}_{2} \mathrm{Cl}_{2}(2 \mathrm{~mL})$, cooled to $0{ }^{\circ} \mathrm{C}, \mathrm{H}_{2} \mathrm{O}_{2} 30 \%(0.1 \mathrm{~mL})$ was added, keeping the stirring for $2 \mathrm{~h}$ at $0{ }^{\circ} \mathrm{C}$, and then, the reaction mixture was diluted with water $(2 \mathrm{~mL})$. The organic phase was dried over $\mathrm{MgSO}_{4}$, filtered, and the solvent was evaporated under reduced pressure to furnish $98 \%$ of a mixture (ratio 2:1) of the unsaturated furanone 21a and its isomer 21b with an endocyclic double bond. The separation of the two isomers by column chromatography through silica gel, using $n$-hexane:ethyl acetate (8:2) as eluent, afforded $21 \mathrm{a}(0.0055 \mathrm{~g}, 44 \%$ yield $)$ as a colorless oil; ${ }^{1} \mathrm{H} \mathrm{NMR}$ (300 MHz, $\left.\mathrm{CDCl}_{3}\right) \delta 7.1-6.6(\mathrm{~m}, 3 \mathrm{H}), 6.4$ (d, J $\left.6.3 \mathrm{~Hz}, 1 \mathrm{H}\right), 6.3$ $(\mathrm{d}, J 1.5 \mathrm{~Hz}, 1 \mathrm{H}), 6.2(\mathrm{~d}, J 1.5 \mathrm{~Hz}, 1 \mathrm{H}), 5.2(\mathrm{~d}, J 6.6 \mathrm{~Hz}, 1 \mathrm{H}), 5.2$ (d, J6.6 Hz, 1H), 4.8 (br d, J6.3 Hz, 1H), 3.4 (s, 3H); ${ }^{13} \mathrm{CNMR}$ $\left(75 \mathrm{MHz}, \mathrm{CDCl}_{3}\right) \delta 168.2,158.9,154.9,134.0,131.5,126.5$, 113.0, 108.1, 105.8, 104.8, 94.6, 56.7, 46.0; IR $v_{\max } / \mathrm{cm}^{-1}: 2995$, $1728,1475,1207,1023,845,735 ; \mathrm{MS} \mathrm{m} / z$ (relative intensity) $203\left(\mathrm{M}^{+}-\mathrm{CH}_{2} \mathrm{OCH}_{3}, 100\right), 173$ (95), 145 (98), 131 (35), 115 (37), 91 (20), 77 (16).

4-(Methoxyme thoxy)-3-methylene-2,3,3a,8atetrahydrofuro[2,3-b][1]benzofuran (23). Diisobutylaluminium hydride (DIBAL-H) $(0.030 \mathrm{~mL}, 0.033 \mathrm{mmol}, 1.0$ mol L $\mathrm{L}^{-1}$ in toluene) was added to a stirred solution of compound 21a $(0.0049 \mathrm{~g}, 0.020 \mathrm{mmol})$ in toluene $(2 \mathrm{~mL})$, cooled at $-78{ }^{\circ} \mathrm{C}$, under anhydrous conditions. After a onehour stirring at $-78^{\circ} \mathrm{C}$, the dry ice bath was removed, and a mixture of crushed ice $(1 \mathrm{~g})$, acetic acid $(0.3 \mathrm{~mL})$ and $\mathrm{CHCl}_{3}$
(7 mL) was added. This mixture was stirred for $30 \mathrm{~min}$, the organic phase was separated, washed with saturated solution of $\mathrm{NaHCO}_{3}$ and with saturated brine, and dried over $\mathrm{MgSO}_{4}$. The solvent was filtered and evaporated under reduced pressure, to yield the crude compound 22, which was used in the following step without further purification. Then, to a stirred solution of compound 22 in $\mathrm{CH}_{2} \mathrm{Cl}_{2}(4 \mathrm{~mL})$, cooled at $-78^{\circ} \mathrm{C}$ under anhydrous conditions, triethylsilane $(0.010$ $\mathrm{mL}, 0.06 \mathrm{mmol})$ and trifluoroacetic acid $(0.005 \mathrm{~mL}, 0.06$ mmol) were added. After $1 \mathrm{~h}$, a solution of $5 \% \mathrm{NaHCO}_{3}(2$ $\mathrm{mL}$ ) was added, and the mixture was quickly stirred at room temperature for $10 \mathrm{~min}$. The organic phase was washed with a saturated solution of $\mathrm{NaHCO}_{3}$ and with saturated brine, dried over $\mathrm{MgSO}_{4}$, filtered, and the solvent was evaporated under reduced pressure. The residue was purified by column chromatography through silica gel, using $n$-hexane:ethyl acetate (8:2) as eluent, to afford $23(0.0034 \mathrm{~g}, 72 \%)$ as a colorless oil; ${ }^{1} \mathrm{H}$ NMR $\left(300 \mathrm{MHz}, \mathrm{CDCl}_{3}\right) \delta 7.0-6.4(\mathrm{~m}, 3 \mathrm{H})$, $6.3(\mathrm{~d}, J 5.6 \mathrm{~Hz}, 1 \mathrm{H}), 5.4$ (br d, $J 1.5 \mathrm{~Hz}, 1 \mathrm{H}), 5.2$ (d, J $6.8 \mathrm{~Hz}$, $1 \mathrm{H}), 5.1$ (d, J6.8 Hz, 1H), 5.0 (brd, J1.5 Hz, 1H), 4.4 (m, 3H), $3.4(\mathrm{~s}, 3 \mathrm{H}) ;{ }^{13} \mathrm{C} \mathrm{NMR}\left(75 \mathrm{MHz}, \mathrm{CDCl}_{3}\right) \delta 160.2,154.7,146.6$, 130.3, 112.7, 108.1, 106.9, 105.6, 103.8, 94.4, 70.9, 56.5, 49.8; IR $v_{\max } / \mathrm{cm}^{-1}: 2999,1600,1475,1203,1020,845,735$; MS $m / z$ (relative intensity) 189 [ $\left.\left(\mathrm{M}^{+}-\mathrm{CH}_{2} \mathrm{OCH}_{3}\right), 8\right], 134$ (28), 89 (70), 45 (54).

3-Methylene-2,3,3a,8a-tetrahydrofuro[2,3b][1]benzofuran-4-ol (24). A catalytic amount of concentrated $\mathrm{HCl}$ was added through a capillary tube to a stirred solution of compound $23(0.0031 \mathrm{~g}, 0.013 \mathrm{mmol})$ in methanol $(5 \mathrm{~mL})$. The reaction mixture was stirred at room temperature for $24 \mathrm{~h}$. The solvent was removed under reduced pressure, and the residue was purified by column chromatography through silica gel, using $n$-hexane:ethyl acetate (7:3) as eluent, to afford $24(0.0019 \mathrm{~g}, 80 \%)$ as a colorless oil; ${ }^{1} \mathrm{H}$ NMR (300 $\left.\mathrm{MHz}, \mathrm{CDCl}_{3}\right) \delta 7.0(\mathrm{~s}, 1 \mathrm{H}), 7.0-6.3(\mathrm{~m}, 3 \mathrm{H}), 6.3(\mathrm{~d}, J 5.8 \mathrm{~Hz}$, $1 \mathrm{H}), 5.4(\mathrm{dd}, J 2.0$ and $3.5 \mathrm{~Hz}, 1 \mathrm{H}), 5.01(\mathrm{dd}, J 2.0$ and $3.2 \mathrm{~Hz}$, 1H), 4.4 (br d, J 5.8 Hz, 1H), 4.4 (m, 2H); ${ }^{13} \mathrm{C} \mathrm{NMR}(75 \mathrm{MHz}$, $\left.\mathrm{CDCl}_{3}\right) \delta 160.0,153.4,136.6,130.3,112.5,112.3,109.0$, 108.2, 102.9, 71.0, 49.7; IR $v_{\max } / \mathrm{cm}^{-1}: 3338,2995,1475,1209$, $1023,845,735 ; \mathrm{MS} m / z$ (relative intensity) $190\left(\mathrm{M}^{+}, 89\right), 134$ (32), 89 (65), 77 (33), 45 (54).

Methyl (2Z)-3-(4-hydroxy-3-methylene-2,3,3a,8atetrahydrofuro[2,3-b][1]benzofuran-5-yl)acrylate (25) and methyl (2Z)-3-(4-hydroxy-3-methylene-2,3,3a,8atetrahydrofuro[2,3-b][1]benzofuran-7-yl)acrylate (26). A solution of methyl propiolate $(0.0005 \mathrm{~g}, 0.006 \mathrm{mmol})$ in $\mathrm{CH}_{2} \mathrm{Cl}_{2}(2 \mathrm{~mL})$ was slowly added $(10 \mathrm{~min})$ to a stirred solution of triphenylphosphine $(0.0017 \mathrm{~g}, 0.006 \mathrm{mmol})$ and compound 24 (0.0012 g, $0.0063 \mathrm{mmol})$ in $\mathrm{CH}_{2} \mathrm{Cl}_{2}(1 \mathrm{~mL})$, cooled at $-5{ }^{\circ} \mathrm{C}$. The ice bath was removed, and the reaction mixture was stirred at room temperature for $24 \mathrm{~h}$. The solvent 
was removed under reduced pressure, and the residue was purified by column chromatography through silica gel, using $n$-hexane:ethyl acetate (7:3) as eluent, to afford a mixture of compounds 25 and $26(0.0014 \mathrm{~g}, 81 \%)$ as a colorless oil; Analytical data for compound 25: ${ }^{1} \mathrm{H}$ NMR $(300 \mathrm{MHz}$, $\left.\mathrm{CDCl}_{3}\right) \delta 7.80\left(\mathrm{~d}, J 12.1 \mathrm{~Hz}, \mathrm{H}_{4}\right), 6.61\left(\mathrm{~d}, J 8.2 \mathrm{~Hz}, \mathrm{H}_{5}\right), 6.53$ (d, $\left.J 8.2 \mathrm{~Hz}, \mathrm{H}_{6}\right), 6.36\left(\mathrm{~d}, J 5.8 \mathrm{~Hz}, \mathrm{H}_{2}\right), 5.63(\mathrm{~d}, J 12.1 \mathrm{~Hz}$, $\mathrm{H}_{3}$ ), 5.28 (ddd, $J 2.3,1.6$ and $\left.1.5 \mathrm{~Hz}, 1 \mathrm{H}_{4^{\prime}}\right), 5.06\left(\mathrm{~m}, 1 \mathrm{H}_{4^{*}}\right.$ ), $4.41\left(\mathrm{~d}, J 5.8 \mathrm{~Hz}, \mathrm{H}_{3}\right), 4.36\left(\mathrm{dt}, J 12.3\right.$ and $\left.1.6 \mathrm{~Hz}, 1 \mathrm{H}_{5}\right), 4.32$ $\left(\mathrm{m}, 1 \mathrm{H}_{5}\right), 3.75\left(\mathrm{~s}, 3 \mathrm{H}_{1}\right) ;{ }^{13} \mathrm{C} \mathrm{NMR}\left(75 \mathrm{MHz}, \mathrm{CDCl}_{3}\right) \delta 177.8$ $\left(\mathrm{C}_{2}\right), 162.0(\mathrm{C}$ arom $), 154.6$ (C arom), $146.2\left(\mathrm{C}_{4}\right), 142.7\left(\mathrm{C}_{4}\right)$, $131.2(\mathrm{CH}$ arom $), 116.7\left(\mathrm{C}_{3}\right), 113.7(\mathrm{C}$ arom $), 111.6\left(\mathrm{C}_{2}\right)$, $109.0(\mathrm{C}$ arom $), 108.9\left(\mathrm{C}_{4^{\prime}}\right), 104.8(\mathrm{CH}$ arom $), 70.5\left(\mathrm{C}_{5^{\prime}}\right)$, $53.3\left(\mathrm{C}_{3}\right), 52.0\left(\mathrm{C}_{1}\right)$. Analytical data for compound $26:{ }^{1} \mathrm{H}$ $\operatorname{NMR}\left(300 \mathrm{MHz}, \mathrm{CDCl}_{3}\right) \delta 7.66\left(\mathrm{~d}, J 12.4 \mathrm{~Hz}, \mathrm{H}_{4}\right), 7.18(\mathrm{~d}, J$ $\left.8.1 \mathrm{~Hz}, \mathrm{H}_{6}\right), 6.68\left(\mathrm{~d}, J 8.1 \mathrm{~Hz}, \mathrm{H}_{5}\right), 6.43\left(\mathrm{~d}, J 5.6 \mathrm{~Hz}, \mathrm{H}_{2}\right), 5.34$ $\left(\mathrm{d}, J 12.4 \mathrm{~Hz}, \mathrm{H}_{3}\right), 5.15\left(\mathrm{~m}, 1 \mathrm{H}_{4^{\prime}}\right), 5.11\left(\mathrm{~m}, 1 \mathrm{H}_{4^{\prime}}\right), 4.48(\mathrm{~d}, J$ $\left.5.6 \mathrm{~Hz}, \mathrm{H}_{3}\right), 4.42\left(\mathrm{~m}, 2 \mathrm{H}_{5}\right), 3.73\left(\mathrm{~s}, 3 \mathrm{H}_{1}\right) ;{ }^{13} \mathrm{C} \mathrm{NMR}(75$ $\left.\mathrm{MHz}, \mathrm{CDCl}_{3}\right) \delta 178.0\left(\mathrm{C}_{2}\right), 161.8(\mathrm{C}$ arom $), 159.9(\mathrm{C}$ arom $)$, $148.3\left(\mathrm{C}_{4}\right), 139.9\left(\mathrm{C}_{4}\right), 131.5(\mathrm{CH}$ arom $), 114.8(\mathrm{C}$ arom $)$, $113.9\left(\mathrm{C}_{3}\right), 113.1\left(\mathrm{C}_{2}\right), 112.2(\mathrm{CH}$ arom $), 109.9\left(\mathrm{C}_{4}\right), 108.7$ (C arom), $71.1\left(\mathrm{C}_{5}\right), 55.4\left(\mathrm{C}_{3}\right), 51.9\left(\mathrm{C}_{1}\right)$. IR $v_{\max } / \mathrm{cm}^{-1}$ : mixture of 25 and 26: 3388, 2917-2841, 1717, 1654-1467, 1128; MS $m / z$ quasi ion $[\mathrm{M}+\mathrm{H}]^{+}$in 275 .

\section{Acknowledgments}

The authors wish to thank the Fundação de Amparo à Pesquisa do Estado de São Paulo (FAPESP), the Coordenadoria de Aperfeiçoamento de Pessoal do Ensino Superior (CAPES), and the Conselho Nacional de Desenvolvimento Científico e Tecnológico (CNPq) for financial support.

\section{References}

1. Murray, R. D. H.; Mendez, J.; Brown, S. A.; The Natural Coumarins: Occurrence, Chemistry and Biochemistry; Wiley: New York, 1982; Maes, C. M.; Steyn, P. S.; J. Chem. Soc., Perkin Trans. 1 1984, 1137; Gorst-Allman, C. P.; Steyn, P. S.; J. Chem Soc., Perkin Trans. 1 1987, 163; Minto, R. E.; Townsend, C. A.; Chem. Rev. 1997, 97, 2537; Townsend, C. A.; Minto, R. E. In Comprehensive Natural Products Chemistry; Barton, D.; Nakanishi, K.; Meth-Cohn, D.; Sankawa, V., eds.; Elsevier: Oxford, 1999, vol. 1, ch 1.17; Lorenzo, E.; Alonso, F; Yus, M.; Tetrahedron 2000, 56, 1745; Trost, B. M.; Toste, F. D.; J. Am. Chem. Soc. 2003, 125, 3090.

2. Pirrung, M. C.; Lee, Y. R.; J. Am. Chem. Soc. 1995, 117, 4814.

3. Chandra-Mouli, G. V. P.; Reddy, Y. D.; Somayajulu,V. V.; Tetrahedron 1983, 39, 2277.
4. Tantivatana, P.; Ruangrungsi, N.; Vaisiriroj, V.; Lankin, D. C.; Bhacca, N. S.; Borris, R. P.; Cordell, G. A.; Johnson, L-R. F.; J. Org. Chem. 1983, 48, 268; Rahmani, M.; Taufiq-Yap, Y. H.; Ismail, H. B. M.; Sukari, M. A.; Manas, A. R.; Planta Medica 1993, 59, 93; Rahmani, M.; Taufiq-Yap, Y. H.; Ismail, H. B. M.; Sukari, M. A.; Waterman, P. G.; Phytochemistry 1994, 37, 561; Kamperdick, C.; Phuong, N. M.; Sung, T. V.; Schmidt, J.; Adam, G.; Phytochemistry 1999, 52, 1671.

5. Donate, P. M.; da Silva, R.; da Silva, G. V. J.; Aleman, C.; Synth. Commun. 2001, 31, 141; Aleman, C.; Donate, P. M.; da Silva, R.; da Silva, G. V. J.; J. Org. Chem. 1999, 64, 5712.

6. Snider, B. B.; Chem. Rev. 1988, 88, 793; Snider, B. B.; Hui, R. A. H. F.; Kulkarni, Y. S.; J. Am. Chem. Soc. 1985, 107, 2194; Snider, B. B.; Hui, R. A. H. F.; J. Org. Chem. 1985, 50, 5167.

7. Brady, W. T.; Marchand, A. P.; Giang, Y. F.; Wu, A. H.; Synthesis 1987, 395; Brady, W. T.; Giang, Y. F.; J. Org. Chem. 1985, 50, 5177.

8. Miller, J. M.; So, K. H.; Clark, J. H.; Can. J. Chem. 1979, 57, 1887.

9. Corey, E. J.; Danheiser, R. L.; Chandrasekaran, S.; Siret, P.; Keck, G. E.; Gras, J. L.; J. Am. Chem. Soc. 1978, 100, 8031.

10. Stork, G.; Takahashi, T.; J. Am. Chem. Soc. 1977, 99, 1275.

11. Koreeda, M.; Dixon, L. A.; Hsi, J. D.; Synlett 1993, 555.

12. Poos, G. I.; Arth, G. E.; Beyler, R. E.; Sarett, L. H.; J. Am. Chem. Soc. 1953, 75, 422.

13. Koreeda, M.; Patel, P. D.; Brown, L.; J. Org. Chem. 1985, 50, 5910.

14. Auerbach, J.; Weinreb, S. M.; J. Chem. Soc., Chem. Commun. 1974, 298.

15. House, H. O.; Modern Synthetic Reactions; W. A. Benjamin: New York, $2^{\text {nd }}$ ed., 1972, ch. 6; Dave, V.; Warnhoff, E. W.; J. Org. Chem. 1983, 48, 2590.

16. Grieco, P. A.; Nishizawama, M.; J. Org. Chem. 1977, 42, 1717.

17. Kraus, G. A.; Frazier, K. A.; Roth, B. D.; Taschner, M. J.; Neuenschwander, K.; J Org. Chem. 1981, 46, 2417.

18. Sethna, S.; Phadke, R.; Organic Reaction, Wiley: New York, 1975, vol. 7, ch 1.

19. Hoefnagel, A. J.; Gunnewegh, E. A.; Downing, R. S.; van Bekkum, H.; J. Chem. Soc., Chem Commun. 1995, 225.

20. Yavari, I.; Heckmat-Shoar, R.; Zonouzi, A.; Tetrahedron Lett. 1998, 39, 2391.

21. Cartwright, G. A.; McNab, H.; J. Chem. Res. (S) 1997, 296; Black, M.; Cadogan, J. I. G.; McNab, H.; MacPherson, A. D.; Roddam, V. P.; Smith, C.; Swenson, H. R.; J. Chem. Soc., Perkin Trans. 1 1997, 2483.

Received: July 8, 2004 Published on the web: March 4, 2005

FAPESP helped in meeting the publication costs of this article. 